\title{
IMPLEMENTASI MODEL PEMBELAJARAN KOOPERATIF THINK PAIR SHARE (TPS) UNTUK MENINGKATKAN HASIL BELAJAR PASSING BOLA VOLI
}

\author{
Ketut Suliaji $^{1}$ \\ 1 SMAN 3 Amlapura \\ Karangasem, Bali \\ e-mail: ketutsuliaji24@gmail.com
}

\begin{abstract}
Abstrak
Tujuan penelitian ini adalah untuk meningkatkan hasil belajar passing bola voli pada siswa kelas XII MIPA3 SMAN 3 Amlapura tahun pelajaran 2018/2019 dengan menerapkan model pembelajaran TPS (Think Pair Share). Jenis penelitian dalam penelitian ini adalah penelitian kelas (PTK). Penelitian ini dilaksanakan 2 siklus dimana masing-masing siklus terdiri dari 3 pertemuan. Subyek penelitian adalah siswa kelas XII MIPA 3 SMAN 3 Amlapura Tahun Pelajaran 2018/2019 berjumlah 35 orang siswa. Hasil penelitian menunjukkan bahwa persentase tingkat penguasaan hasil belajar teknik dasar passing bola voli pada siklus I sebesar $42,86 \%$ berada pada dalam kategori sangat kurang. Pada Siklus II sebesar $85,71 \%$ berada pada berada dalam kategori baik. Terjadi peningkatan persentase tingkat penguasaan hasil belajar teknik dasar passing in bola voli sebesar $42,85 \%$ dari siklus I ke siklus II. Disimpulkan bahwa model pembelajaran Think Pair Share (TPS) dapat meningkatkan hasil belajar passing bola voli.
\end{abstract}

Kata-kata kunci : model pembelajaran kooperatif TPS, hasil belajar, passing bola voli

\begin{abstract}
Abstrack
The aimed of this study was to improve learning outcomes volleyball in class XII MIPA3 students of SMAN 3 Amlapura by applying the TPS (Think Pair Share) learning model. This study was a classroom action research CAR). This research was conducted in 2 cycles where each cycle consisted of 3 meetings. The subjects of the research were students of class XII MIPA 3 of SMAN 3 Amlapura totaling 35 students. The results showed that the percentage of mastery learning outcomes of volleyball passing in the first cycle was $42.86 \%$ in the very poor category and in Cycle II $85.71 \%$ were in the good category. An increase in the percentage of mastery levels of learning outcomes of of passing volleyball by $42.85 \%$ from cycle I to cycle II. it was concluded that the Think Pair Share (TPS) learning model could improve volleyball passing learning outcomes.
\end{abstract}

Keywords : cooperative learning TPS, learning outcomes, passing volleyball.

\section{PENDAHULUAN}

Kualitas kehidupan bangsa sangat ditentukan oleh factor pendidikan. Kemajuan suatu bangsa hanya dapat dicapa imelalui penataan pendidikan yang baik (Nurhadi, dkk.2004:1). Peran pendidikan sangat penting untuk menciptakan kehidupan yang cerdas, damai, terbuka, dan demokratis. Oleh karena itu, pembaruan pendidikan harus selalu dilakukan untuk meningkatkan kualitas pendidikan nasional. Pendidikan Jasmani, Olahraga, Dan Kesehatan (PJOK) merupakan bagian integral dari pendidikan secara keseluruhan, bertujuan untuk mengembangkan aspek kebugaran 
jasmani, keterampilan gerak, keterampilan berpikir kritis, keterampilan sosial, penalaran, stabilitas emosional, tindakan moral, aspek pola hidup sehat dan pengenalan lingkungan bersih melalui aktivitas jasmani, olahraga dan kesehatan terpilih yang direncanakan secara sistimatis dalam rangka mencapai tujuan pendidikan nasional (Samsudin, 2008). Proses pembelajaran PJOK prinsipnya adalah serangkaian kegiatan mulai dari perencanaan, pelaksanaan, dan penilaian sampai pada tindak lanjut dalam usaha mencapai tujuan. Kegiatan belajar mengajar dapat berjalan dengan baik dan lancar, jika terjadi keharmonisan antara siswa dan lingkungan belajar yang diatur oleh guru.

PJOK termasuk salah satu upay auntuk mewujudkan manusia seutuhnya yang diselenggarakan di sekolah, baik dari jenjang pendidikan dasar sampai menengah. PJOK yang diajarkan di sekolah memiliki peranan sangat penting, yaitu memberikan kesempatan kepada peserta didik untuk terlibat langsung dalam berbagai pengalaman belajar melalui kegiatan aktivitas jasmani

Pembekalan pengalaman belajar itu diarahkan untuk membina pertumbuhan fisik dan pengembangan psikis yang lebih baik, sekaligus membentuk pola hidup sehat dan bugar sepanjang hayat. Pencapaian tujuan PJOK di sekolah sebaiknya mempertimbangkan tujuan pembelajaran, kemampuan siswa, metode, materi, sarana dan prasarana, aktivitas belajar serta kesenangan siswa. Unsurunsur tersebut di atas harus diperhatikan, agar proses pembelajaran dapat berjalan dengan baik dan sukses, sehingga tujuan yang diharapkan akan tercapai. Cabang olahraga permainan merupakan salah satu isi kurikulum yang cukup mendominasi dalam mata pelajaran PJOK di sekolah. Olahraga permainan tersebut diantaranya permainan permainan bola besar yaitu bola voli.

Dilihat dari hasil belajar bola voli salah satunya pada materi passing di kelas
XII MIPA 3 SMAN 3 Amlapura belum menunjukkan hasil yang memuaskan. Sebagian besar siswa hasil belajar passing bola voli masih masih dibawah KKM. Banyak faktor yang menyebabkan hasil belajar masih kurang diantaranya sarana dan prasarana yang masih kurang terutana ketersediaan bola, siswa kurang aktif dalam pembelajaran serta siswa yang sudah bisa terlalu mendominasi kegiatan pemebelajarn. Untuk itu diupayakan suatu strategi untuk meningkatkan hasil belajar siswa salah satunya adalah dengan penerapan model pembelajaran yang berpusat pada siswa serta memberikan tanggung jawab lebih kepada siswa yang sudah bisa untuk berbagi ilmu dengan temannya, salah satunya adalah melalui model pembelajaran kooperatif TPS.

Menurut Nasution, (2005: 279) menyatakan "pembelajaran kooperatif merupakan sebuah kelompok strategi pengajaran yang melibatkan siswa bekerja secara berkolaborasi untuk mencapai tujuan bersama". Senada dengan itu Nurhadi, dkk. (2004: 60), menyatakan pembelajaran kooperatif merupakan pendekatan pembelajaran melalui penggunaan kelompok kecil siswa untuk bekerjasama dalam memaksimalkan kondisi belajar dalam mencapai tujuan belajar". Dengan menerapkan model pembelajaran kooperatif tipe Think-PairShare (TPS) yang bertujuan mengajak para siswa lebih berperan aktif dalam proses pembelajaran pendidikan jasmani khususnya dalam pembelajaran permainan bola voli materi passing. Dalam model pembelajaran ini, siswa belajar dalam kelompok-kelompok kecil untuk mempelajari materi dan memecahkan masalah yang diberikan, serta siswa diberi kesempatan untuk membangun pengetahuannya sendiri dengan member makna pada setiap materi yang dipelajari melalui pengalaman nyata. Pengalaman akan lebih bermakna manakala siswa memperoleh aktivitas secara bervariasi. Variasi aktivitas belajarakan memberikan tantangan dan masalah yang bervariasi 
juga. Variasi masalah dan tantangan tersebut menyebabkan pengalaman menjadilebih bermakna. Siswa yang mampu menyelesaikan materi dan permasalahan yang diberikanakan diberi penghargaan secarakelompok dengan demikian siswa akan berusaha menguasai materi dengan sebaik-baiknya. Tujuan penelitian yang ingin dicapai adalah untuk meningkatkan aktivitas dan hasil belajar teknik dasar bermain bola voli melalui implementasi model pembelajaran kooperatif tipe TPS pada siswa kelas XII MIPA 3 SMAN 3 Amlapura tahun pelajaran 2018/2019

\section{METODOLOGI PENELITIAN}

Jenis penelitian dalam penelitian ini adalah penelitian kelas (PTK). Penelitian tindakan kelas adalah suatu bentuk penelitian yang bersifat reflektif dengan melakukan tindkan-tindakan tertentu agar dapat memperbaiki dan atau meningkatkan praktek-praktek pembelajaran di kelas secara profesional (Ari Maryani, 2005 : 25).

Dalam penelitian ini, jenis penelitian tindakan yang digunakan oleh guru sebagai peneliti yaitu untuk meningkatkan praktek-praktek pembelajaran di kelas dimana guru terlibat secara penuh dalam proses perencanaan, aksi (tindakan), dan refleksi. Dalam penelitian ini guru mencari problema sendiri untuk dipechkan melalui penelitian tindakan kelas. Jika melibatkan pihak lain pada penelitian ini, peranan guru tidak dominan.

Penelitian ini dilaksanakan 2 siklus dimana masing-masing siklus terdiri dari 3 pertemuan. $2 \mathrm{x}$ pertemuan untuk proses pembelajaran dan $1 \mathrm{x}$ pertemuan untuk evaluasi penilaian. Subyek penelitian adalah siswa kelas XII MIPA 3 SMAN 3 Amlapura tahun pelajaran 2018/2019 berjumlah 35 orang siswa, yang terdiri dari 14 orang putri, dan 21 orang putra.

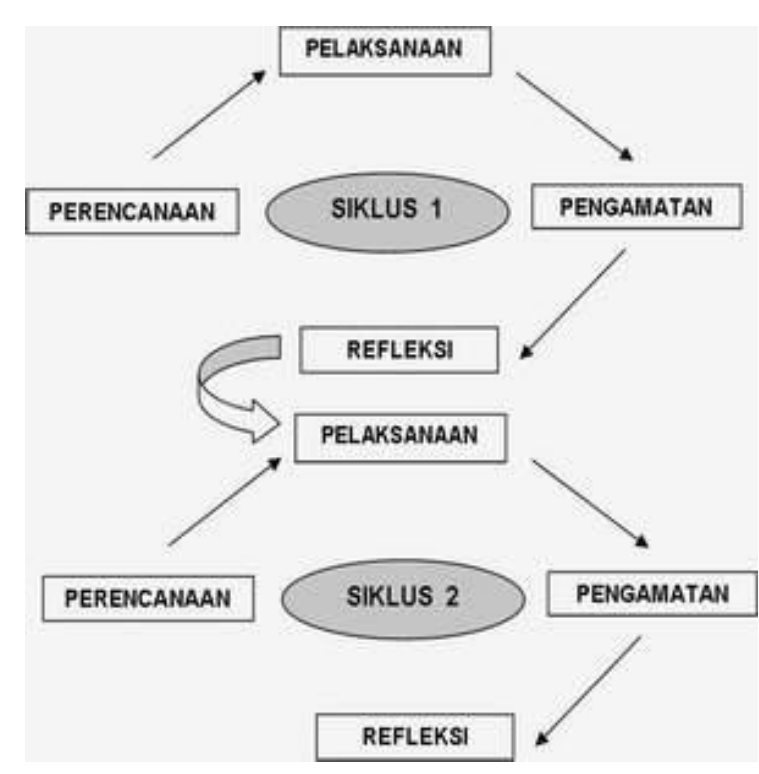

Gambar 1. Rancangan Penelitian Tindakan Kelas

\section{HASIL DAN PEMBAHASAN Hasil Penelitian}

Penelitian dilaksanakan sebanyak 2 siklus dengan masing-masing siklus terdiri dari tahap perencanaan, pelaksanaan, observasi, dan refleksi. Data siklus I menunjukkan Siswa yang memperoleh nilai A (sangat Baik) 2 orang siswa, nilai B (baik) 2 orang siswa, nilai $\mathrm{C}$ (cukup) 11 orang siswa, nilai D (kurang) 15 orang siswa, dan nilai E (sangat Kurang) 5 orang siswa. Dari data tersebut tingkat penguasaan materi secara klasikal oleh siswa adalah $42,86 \%$ berada pada kategori sangat kurang.

Dari hasil refleksi ditemukan beberapa kendala dalam pelaksanaan siklus I yaitu kurangnya komunikasi aktif antar kelompok dalam TPS, kurang sarana bola dalam kegiatan sehingga proses pembelajaran tidak berlangsung optimal, serta kurang lembar penilaian untuk siswa saling mengkoreksi kegiatan belajar yang sudah dilakukan. Berdasarkan observasi tersebut maka di siklus II dibuat perencanaan sesuai dengan hasil refleksi yaitu mengintensifkan komunikasi dengan merombak ulang kelompok kooperatif, 
menyediakan bola yang dimodifikasi (bola karet) sesuai dengan jumlah kelompok serta membuat lembar refleksi diri untuk masing-masing kelompok terkait gerakan passing bola voli.

Hasil analisis data dari siklus II penguasaan siswa terhadap materi yang diberikan mengalami peningkatan dari kategori sangat kurang menjadi baik. Adapun hasil belajar siswa pada siklus II mencapai tingkat kelulusan secara klasikal sebesar $85,71 \%$ berada pada kategori Baik dengan rata-rata tingkat kelulusan secara individu sebagai berikut : siswa yang memperoleh nilai A (sangat baik) 8 orang siswa, nilai B (baik) 11 orang siswa, nilai C (cukup) 11 orang siswa, dan nilai D (kurang) 5 orang siswa, sedangkan untuk nilai E (sangat kurang) tidak ada.

Sehingga secara umum dapat dikatakan bahwa penerapan model pembelajaran kooperatif tipe TPS untuk meningkatkan hasil belajar teknik dasar bermain bola voli pada siswa kelas XII MIPA 3 SMAN 3 Amlapura pada semester pertama tahun pelajaran 2018/2019 efektif untuk meningkatkan hasil belajar siswa. Terjadi peningkatkan hasil belajar secara klasikal sebesar $42,85 \%$ dari siklus I ke siklus II.

\section{Pembahasan}

Berdasarkan analisis data di atas ditemukan bahwa model pembelajaran kooperatif tipe TPS dapat meningkatkan hasil belajar passing bola voli siswa dengan peningkatan sebesar $42,85 \%$ dari siklus I yang awalnya $42,86 \%$ menjadi $85,71 \%$ pada siklus II. Peningkatkan ini disebabkan karena dalam pembelajaran kooperatif tipe TPS siswa dibelajarkan untuk saling membantu teman satu kelompoknya dalam menguasai materi yang diberikan. Siswa yang lebih pintar menjadi tutor atau mengajarkan siswa yang kurang. Siswa juga diajarkan untuk beratnggungjawab agar setiap anggota tim memperoleh atau dapat menguasai keterampilan passing bola voli yang diajarkan, sebab keberhasilan kelompok ditentukan oleh keberhasilan masingmasing individu dalam kelompok tersebut. Hal ini sesuai dengan pendapat Arends (2008) bahwa model pembelajaran TPS dapat mengaktifkan seluruh siswa selama proses pembelajaran dan memberikan kesempatan untuk bekerja sama antar siswa yang mempunyai kemampuan heterogen. Model ini efektif untuk diskusi kelas karena prosedur yang digunakan dapat memberi siswa lebih banyak waktu untuk berpikir dan saling membantu.

Senada dengan itu, Sanjaya (2009) menyebutkan bahwa interaksi tatap muka dalam pembelajaran kooperatif akan memberikan kesempatan bagi setiap anggota kelompok untuk bertatap muka saling memberikan informasi dan saling membelajarkan. Hal ini akan menyebabkan siswa saling mengisi untuk bertukar informasi.

Penelitian mengenai efektifitas pembelajaran TPS juga pernah dilakukan oleh beberapa peneliti yaitu Surayya (2014) yang menemukan bahwa terdapat perbedaan hasil belajar IPA antara siswa yang dibelajarkan menggunakan model pembelajaran kooperatif tipe TPS dengan siswa yang dibelajarkan dengan model pembelajaran konvensional dimana siswa yang diajarkan dengan model pembejaran TPS memperoleh hasil belajar IPA yang lebih baik.

Penelitian sejenis juga dilakukan oleh Muthoharoh (2017) yang menemukan berdasarkan hasil penelitian bahwa hasil belajar Bahasa inggris peserta didik yang diajar dengan model pembelajaran Think Pair Share lebih tinggi dibandingkan hasil belajar bahasa inggris peserta didik yang diajar dengan metode kovensional.

Berdasarkan hal tersebut model ini cocok diterapkan apabila ingin meningkatkan hasil belajar passingbola voli. Penerapan model pembelajaran TPS ini disertai catatan bahwa diperlukan kesiapan dan keterlibatan siswa secara aktif agar penerapan model pembelajaran ini menjadi efektif. 


\section{SIMPULAN DAN SARAN}

Simpulan

Berdasarkan hasil analisis data dan pembahasan dapat disimpulkan bahwa penerapan model pembelajaran kooperatif tipe TPS efektif untuk meningkatkan hasil belajar teknik dasar bermain bola voli. Hal ini dapat dilihat dari persentase ketuntasan siswa secara klasikal pada siklus I sebesar $42,86 \%$ berada pada rentang $<55 \%$ dalam kategori sangat kurang. Sedangkan pada siklus II rata persentase ketuntasan belajar secara klasikal sebesar $85,71 \%$ berada pada rentang $80 \%$ - $89 \%$ dalam kategori baik. Jadi dari hasil data siklus I ke siklus II terjadi peningkatan persentase ketuntasan siswa secara klasikal terhadap materi teknik dasar bermain bola voli sebesar $42,85 \%$.

\section{Saran-saran}

Berdasarkan simpulan di atas dapat diajukan saran-saran sebagai berikut :

1. Disarankan kepada guru-guru penjas di SMAN 3 Amlapura, maupun di kabupaten karangasem dalam meningkatkan hasil belajar teknik dasar bermain bola voli hendaknya merancang program pembelajaran dan penguasaan model pembelajaran kooperatif tipe TPS, sehingga dapat meningkatkan hasil belajar siswa serta meningkatkan profesionalisme guru pengajar bidang studi.

2. Disarankan kepada peneliti lain dalam melakukan penelitian dapat menggunakan model pembelajaran kooperatif tipe TPS untuk meningkatkan hasil belajar yang diinginkan.

\section{DAFTAR PUSTAKA}

Arends, R.I. 2008. Learning To Teach: Belajar untuk Mengajar Buku Dua. Yogyakarta: Pustaka Belajar.

Ari, Maryani Nyoman. 2005. Penerapan Pembelajaran dengan Menggunakan Media Video Cassette Disc (VCD) Terhadap Hasil Belajar Lompat Jauh Gaya Menggantung pada Siswa Kelas VIIA SMP Negeri 3 Singaraja. Skripsi IKIP Negeri Singaraja (tidak diterbitkan).

Muthoharoh, N. B. 2017. Pengaruh Model Pembelajaran Kooperatif" Think Pair Share" terhadap Hasil Belajar Bahasa Inggris. SAP (Susunan Artikel Pendidikan), 2(1).

Nasution. S. 2005. Berbagai Pendekatan dalam Proses Belajar dan Mengajar. Bumi Aksara.

Nurhadi. Dkk. 2004. Pembelajaran Kontekstual. Universitas Negeri Malang.

Samsudin. 2008. Pembelajaran Pendidikan Jasmani Olahraga dan Kesehatan SMP/MTs. Jakarta: Prenada Media Group

Sanjaya, W. 2009. Strategi Pembelajaran Berorientasi Standar Proses Pendidikan. Jakarta : Prenada

Media Group Surayya, L., Subagia, I. W., Tika, I. N., \& Si, M. (2014). Pengaruh model pembelajaran think pair share terhadap hasil belajar IPA ditinjau dari keterampilan berpikir kritis siswa. Jurnal Pendidikan dan Pembelajaran IPA Indonesia, 4(1). 